\title{
Bottomless lift net for quantitatively sampling nekton on intertidal marshes
}

\author{
Lawrence P. Rozas* \\ Louisiana Universities Marine Consortium, Marine Research and Education Center, Chauvin, Louisiana 70344, USA
}

\begin{abstract}
I describe a $6 \mathrm{~m}^{2}$ bottomless lift net designed to quantitatively sample intertidal, vegetated environments. Major advantages of using the lift net are: (1) requires minimal habitat modification or disturbance in the vicinity of the sampling area, (2) nets may be oriented in any direction and sampling is not confined to sites near navigable water, (3) estimates of nekton density are easily determined from a known sample area, and (4) nets are relatively inexpensive to construct, operate, and maintain. Net efficiencies ranged from $32 \%$ for daggerblade grass shrimp Palaemonetes pugio to $93 \%$ for striped mullet Mugil cephalus. The net was used to sample nekton on a Louisiana salt marsh for 8 mo, during which 8229 organisms, 25 species of fishes and 4 species of decapod crustaceans were collected. Numerically dominant species were daggerblade grass shrimp, Gulf killifish Fundulus grandis, sheepshead minnow Cyprinodon variegatus, diamond killifish Adinia xenica, striped mullet, blue crab Callinectes sapidus, brown shrimp Penaeus aztecus, and white shrimp Penaeus setiferus. The bottomless lift net can be used to compare nekton densities in a variety of intertidal habitats, many of which are difficult or impossible to sample using other methods.
\end{abstract}

\section{INTRODUCTION}

Nekton associated with intertidal vegetation is difficult to study, due largely to the problem of finding an appropriate quantitative sampling method. Although throw traps and drop nets are effective in some habitats, their efficacy is substantially reduced in dense vegetation, and some require considerable habitat modification (Kushlan 1974, 1981).

The drop sampler of Zimmerman et al. (1984) is a substantial improvement over earlier versions, because it does not require habitat modification prior to sampling, and it can be used in dense vegetation. McIvor \& Odum's (1986) flume net and Hettler's (1989) block net can also be used in thick vegetation, and because these devices do not require removing plants from the sampling area, they can be used to collect long-term data by repeatedly sampling the same site. However, all have major drawbacks. The drop sampler, and to a lesser degree the flume and block net, are limited to sampling habitats along the edge of

- Present address: National Marine Fisheries Service, 4700 Avenue U, Galveston, Texas 77551, USA waterways that are navigable by small boat. The flume and block net have 2 other disadvantages. Net walls block access to the sampling area from all but one direction (McIvor \& Odum 1986), and uneven habitat use cannot be determined. For example, organisms collected in a $20 \mathrm{~m}$ flume may have been associated with the marsh-channel interface at the flume mouth, the interior marsh located near the rear of the flume or with any microhabitat in between. Because samples are integrated over time, neither microhabitat-species associations nor precise densities can be determined (Kneib 1991).

Kneib (1991) recently developed the flume weir to overcome these shortcomings. Its use is not limited to sites near open water. The device can be used in any vegetated, intertidal habitat, provided the area can be reached by an elevated walkway, and it was designed to be large enough $\left(100 \mathrm{~m}^{2}\right)$ to overcome some of the problems associated with sampling small areas (Kneib 1991). However, the flume weir is relatively expensive to build and operate, and may be too large for some applications. I describe a $6 \mathrm{~m}^{2}$ bottomless lift net for sampling intertidal marshes. The lift net has many of the advantages of the flume weir (e.g. not restricted to 
sites near open water), and it is much less costly. The net was used successfuliy for 8 mo to sample nekton on a Louisiana, USA, salt marsh.

\section{MATERIALS AND METHODS}

Study area. Sample sites were located on intertidal marshes within the Terrebonne-Timbalier estuary near latitude $29^{\circ} 14^{\prime} \mathrm{N}$ and longitude $90^{\circ} 40^{\prime} \mathrm{W}$, ca $4 \mathrm{~km}$ SW of the Louisiana Universities Marine Consortium (LUMCON) Marine Center at Cocodrie, Louisiana. Tides in the estuary are predominantly diurnal and have a mean range of ca $0.4 \mathrm{~m}$ (Shirzad et al. 1989, U.S. Department of Commerce 1990). Marshes were flooded daily except on equatorial tides. Marsh vegetation was dominated by Spartina alterniflora, although Spartina patens and small patches of Juncus roemerianus were also present. Distichlis spicata was common on marshes of slightly higher elevation (e.g. on the natural levees of tidal creeks).

Net design and site preparation. The bottomless lift net was designed to quantitatively sample the marsh surface with as little modification to the habitat as possible (Fig. 1). Each net $(2 \times 3 \times 1 \mathrm{~m}$ deep) was constructed from $3 \mathrm{~mm}$ mesh, untarred 'Delta' grade nylon netting. Specifications included a $6 \mathrm{~mm}$ diameter nylon rope (length $=6 \mathrm{~m}$ ) sewn along the top of each $3 \mathrm{~m}$ side, and flat sleeves $(15 \mathrm{~cm}$ wide) sewn to the top of each $2 \mathrm{~m}$ side and along the bottom of all 4 sides. I inserted a $2.5 \mathrm{~cm}$ diameter PVC pipe $(2.1 \mathrm{~m}$ long) into each top sleeve and threaded the ends of the nylon ropes (sewn along the $3 \mathrm{~m}$ sides) through holes drilled $2 \mathrm{~cm}$ from each end of the pipes. The 2 ropes at each end of the net were then tied tautly to a brass ring so the ring rested near the center of the $2 \mathrm{~m}$ side. Rigging the net in this fashion insured that all 4 sides of the net lifted simultaneously when the 2 rings were pulled upward and away from each other. Finally, I inserted a lightweight, $10 \mathrm{~m}$ long, galvanized chain through the bottom sleeves, attached the 2 ends of the chain, and sewed adjacent ends of the sleeves together to form one tube of netting that surrounded the chain.

Before nets could be deployed in the field, a series of walkway supports was constructed to each sampling site from the edge of the nearest tidal creek so sites could be reached without trampling marsh vegetation. Portable walkways $(3.8 \times 17 \mathrm{~cm} \times 2.1 \mathrm{~m}$ long with $3.8 \times$ $8.9 \times 30 \mathrm{~cm}$ long legs attached to a $35 \times 35 \mathrm{~cm}$ plywood base on each end) were used to minimize disturbance to the marsh surface while installing walkway supports. Supports made with $3.8 \times 8.9 \mathrm{~cm}$ untreated pine lumber consisted of two $1.5 \mathrm{~m}$ long boards inserted vertically into the marsh about $25 \mathrm{~cm}$ apart and connected by a short crosspiece. Access to sites was
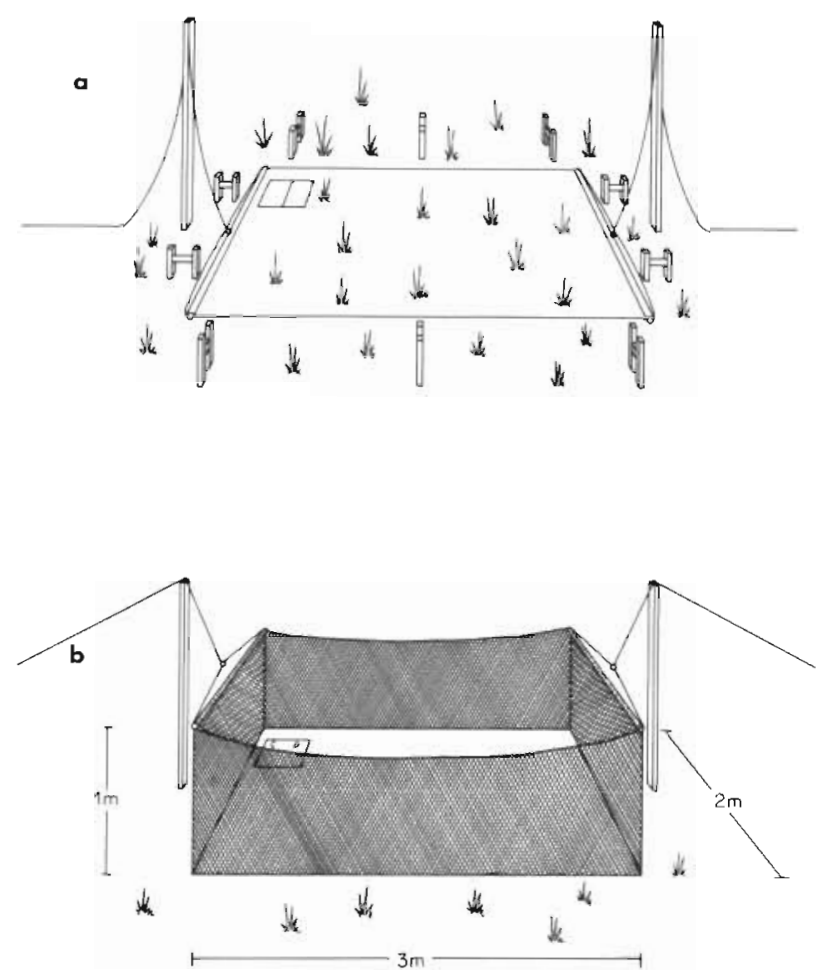

Fig. 1. Diagram of bottomless lift net on the marsh surface (a) prior to sampling when net is buried in marsh substrate and (b) after net walls have been raised to enclose sample. Anchor posts are not illustrated and walkway supports are shown only in top figure. CP: collecting pan

accomplished by walking on wooden planks $(3.8 \times$ $17 \mathrm{~cm} \times 3.1 \mathrm{~m}$ long) placed temporarily over these supports. Supports were also located around the outside of each net ( 2 along $2 \mathrm{~m}$ sides and 3 along $3 \mathrm{~m}$ sides; Fig. 1a). Therefore, one could use temporary walkways (2.1 and $3.1 \mathrm{~m}$ long) to walk around the net perimeter when preparing sites, retrieving samples, or repairing nets. Supports remained in place throughout the study, but walkways were always removed when not in use.

The sample site was prepared by carefully outlining a $2 \times 3 \mathrm{~m}$ rectangle on the marsh surface. I used a templet made from $2 \mathrm{U}$-shaped wooden frames connected by nylon cords to insure a rectangular shape. After removing the templet, a flat hoe was used to slice through the root mat $(20 \mathrm{~cm}$ deep) around the outline of the site. The cut was spread apart at the marsh surface to form a narrow (ca $5 \mathrm{~cm}$ wide) trench. The net was then carefully pushed into the trench until the top of the net was flush with or slightly below the marsh surface. When buried, the net occupied most of the trench volume. After the net was buried, a guide post $(3.8 \times 8.9 \mathrm{~cm} \times 2 \mathrm{~m}$ long) was pushed vertically $1 \mathrm{~m}$ into the marsh at the center of each $2 \mathrm{~m}$ side and about $40 \mathrm{~cm}$ away from the edge of the trench. A $6 \mathrm{~mm}$ diameter rope was threaded through an eye that was 
screwed into the top of the post. One end of the rope was tied to a snap swivel which was attached to the ring at the end of the net, and the opposite end was looped around an anchor post about $12 \mathrm{~m}$ away. Because walkways did not remain in the marsh and net walls were buried in the substrate, nothing impeded the movement of organisms across the marsh surface prior to sampling (Fig. 1a).

I located a collecting pan in a corner of the sampling area (one that appeared to have the lowest elevation) to accumulate organisms as the marsh drained (Kneib 1991). The collecting pan was made by replacing the bottom of a polypropylene container $(30.5 \times 36 \times 17 \mathrm{~cm}$ deep) with $1 \mathrm{~mm}$ mesh Nitex screening. A collecting pit was prepared by digging a hole $(20 \mathrm{~cm}$ deep) into which a wooden frame built to fit snugly around the collecting pan was inserted. The frame prevented slumping around the edges of the hole and was held in place by nailing it to stakes $(3.8 \times 8.9 \mathrm{~cm} \times 1 \mathrm{~m}$ long) pushed entirely into the marsh on the outside of the frame. The collecting pan was inserted into the frame and covered with plywood that was held in place by a rubber strap ( $23 \mathrm{~cm}$ long) stretched over the cover and hooked to nails driven into opposite sides the frame. When properly seated in the frame, the top of the collecting pan was flush with the marsh surface.

Sampling procedure. All samples in the present study were taken by lifting the nets during either day or night at slack high tide in the following manner. Two persons slowly walked to the anchor posts at opposite ends of each net and simultaneously pulled the net walls into their upright position, trapping organisms within the sample area (Fig. 1b). Organisms could not escape by swimming beneath the net, because the bottom remained buried in the trench. After all nets were raised, walkways were used to reach each one to remove plywood covers and allow organisms to enter collecting pans. Samples were retrieved after the marsh surface drained (usually $7 \mathrm{~h}$ after slack high tide) by removing collecting pans and placing the contents into sample bags. Collecting pans were then replaced and covered. Before reinserting the net into the trench, the area along the inside of the net walls was inspected, and organisms were removed using a small dip net. Two persons could walk to a site, retrieve the sample, rebury the net, and return to the boat in 10 to $15 \mathrm{~min}$. Samples were preserved in $20 \%$ formalin for at least $72 \mathrm{~h}$, washed in running water for $24 \mathrm{~h}$, and placed into $70 \%$ ethanol for storage. Organisms were later identified to species and counted. To avoid excessive handling of lift nets and habitat disruption, nets were left buried in place between sampling periods. Prior to (usually 24 h before) each sampling event, nets were lifted to repair holes in the walls and immediately reburied.
Three nets were located on marshes along 3 natural channels for a total of 9 sample sites. Distance from the channel-marsh interface to nets varied from 1.7 to $22.5 \mathrm{~m}$, but most nets were 3 to $7 \mathrm{~m}$ from the nearest channel. Samples were taken 15 times in 1991. monthly in April, May, and October; 2 times in August, September, and November; and 3 times in June and July.

Efficiency estimates. To estimate the efficiency of removing organisms from nets, I added marked animals to sample areas immediately after nets were raised, and calculated the percentage of those retrieved with samples. I conducted efficiency experiments JuneOctober 1991 and February-April 1992 on 8 occasions using 5 species that were abundant on the marsh surface at the time estimates were made: daggerblade grass shrimp Palaemonetes pugio, Gulf killifish Fundulus grandis, sheepshead minnow Cyprinodon variegatus, striped mullet Mugil cephalus, and white shrimp Penaeus setiferus. Organisms were marked by clipping the anal fin of fishes or uropods of shrimp.

\section{RESULTS}

Nekton collected on the marsh surface between April and November 1991 included 25 species of fishes and 4 species of decapod crustaceans, a total of 8229 organisms (Table 1). Daggerblade grass shrimp, Gulf killifish, sheepshead minnows, and diamond killifish Adinia xenica were the most abundant marsh residents. They occurred at an average density of $3.8,1.8$, 1.2 and $0.9 \mathrm{~m}^{-2}$ respectively, and accounted for $75 \%$ of the marsh nekton assemblage. Numerically important transient species were striped mullet, blue crabs Callinectes sapidus, brown shrimp Penaeus aztecus, and white shrimp. Blue crabs and striped mullet were common in marshes throughout the study, whereas the 2 penaeid shrimp were only seasonally abundant. These 4 transient species represented $18 \%$ of the total catch and occurred at lower densities $\left(0.8\right.$ to $\left.0.6 \mathrm{~m}^{-2}\right)$ than dominant resident species.

Efficiency estimates for the bottomless lift net varied substantially among the species tested (Table 2). The net was most efficient at collecting striped mullet $(93 \%)$ and least efficient in taking grass shrimp (32\%).

\section{DISCUSSION}

Efficiencies of the bottomless lift net are comparable to those reported for other devices designed to sample the marsh surface. McIvor \& Odum (1986) estimated flume net efficiencies of 46 to $80 \%$. In their study, as in the present one, grass shrimp were least efficiently sampled. Kneib (1991) reported flume-weir efficien- 
Table 1. List of fishes and decapod crustaceans collected on the marsh surface April-November 1991 using bottomless lift nets. The total catch (no. of individuals) is pooled data for 135 samples of $6 \mathrm{~m}^{2}$ each. Relative abundance (\% total number) is given only when equal to at least $1 \%$. Average density is given only for abundant species

\begin{tabular}{|c|c|c|c|}
\hline Scientific and common name & $\begin{array}{l}\text { Total } \\
\text { catch }\end{array}$ & $\begin{array}{c}\text { Relative } \\
\text { abundance }(\%)\end{array}$ & $\begin{array}{c}\text { Density } \\
\left(\mathrm{m}^{-2}\right)\end{array}$ \\
\hline Palaemonetes pugio Holthuis, daggerblade grass shrimp & 3053 & 37.1 & 3.8 \\
\hline Fundulus grandis Baird \& Girard, Gulf killifish & 1431 & 17.4 & 1.8 \\
\hline Cyprinodon variegatus Lacepede, sheepshead minnow & 973 & 11.8 & 1.2 \\
\hline Adinia Xenica (Jordan \& Gilbert), diamond killifish & 718 & 8.7 & 0.9 \\
\hline Mugil cephalus Linnaeus, striped mullet & 599 & 7.3 & 0.7 \\
\hline Callnectes sapidus Rathbun, blue crab & 476 & 5.8 & 0.6 \\
\hline Penaeus aztecus Ives, brown shrimp & 219 & 2.7 & $0.7^{\mathrm{d}}$ \\
\hline Penaeus setiferus (Linnaeus), white shrimp & 213 & 2.6 & $0.8^{b}$ \\
\hline Menidia beryllina (Cope), inland silverside & 189 & 2.3 & 0.2 \\
\hline Fundulus pulvereus (Evermann), bayou killifish & 115 & 1.4 & 0.1 \\
\hline Fundulus similis (Baird \& Girard), longnose killifish & 91 & 1.1 & 0.1 \\
\hline Gobiosoma bosc (Lacepede), naked goby & 43 & - & - \\
\hline Evorthodus lyricus (Girard), lyre goby & 41 & - & - \\
\hline Gobionellus shufeldti (Jordan \& Eigenmann), freshwater goby & 16 & - & - \\
\hline Poecilia latipinna (Lesueur), sailfin molly & 15 & - & - \\
\hline Bairdiella chrysoura (Lacepede), silver perch & 7 & - & - \\
\hline Cynoscion nebulosus (Cuvier), spotted seatrout & 6 & - & - \\
\hline Myrophis punctatus Lutken, speckled worm eel & 4 & - & - \\
\hline Citharichthys spilopterus Gunther, bay whiff & 3 & - & - \\
\hline Fundulus jenkinsi (Evermann), saltmarsh topminnow & 3 & - & - \\
\hline Gobionellus boleosoma (Jordan \& Gilbert), darter goby & 3 & - & - \\
\hline Lucania parva (Baird \& Girard), rainwater killifish & 3 & - & - \\
\hline Dormitator maculatus (Bloch), fat sleeper & 2 & - & - \\
\hline Archosargus probatocephalus (Walbaum), sheepshead & 1 & - & - \\
\hline Arius felis (Linnaeus), hardhead catfish & 1 & - & - \\
\hline Eucinostomus argenteus Baird \& Girard, spotfin mojarra & 1 & - & - \\
\hline Lagodon rhomboides (Linnaeus), pinfish & 1 & - & - \\
\hline Lutjanus griseus (Linnaeus), gray snapper & 1 & - & - \\
\hline Sciaenops ocellatus (Linnaeus), red drum & 1 & - & - \\
\hline Total nekton & 8229 & & \\
\hline${ }^{d}$ Density April-June, ${ }^{b}$ density August-October & & & \\
\hline
\end{tabular}

Table 2. Results of efficiency estimates for lift nets. Size range and mean ( $\mathrm{mm}_{\mathrm{i}}$ fish: standard length, shrimp: total length), number of tests, number of organisms tested, and mean efficiency \pm 1 SD are given for each species tested

\begin{tabular}{|lcccrc|}
\hline Species & \multicolumn{2}{c}{ Size range (mean) } & Total organisms & Total tests & Efficiency \\
\hline Striped mullet & $25-42$ & $(31)$ & 60 & 6 & $0.93 \pm 0.10$ \\
Gulf killifish & $33-100$ & $(54)$ & 178 & 18 & $0.81 \pm 0.31$ \\
White shrimp & $38-91$ & $(61)$ & 84 & 9 & $0.73 \pm 0.18$ \\
Sheepshead minnow & $25-42$ & $(32)$ & 40 & 5 & $0.58 \pm 0.19$ \\
Daggerblade grass shrimp & $21-39$ & $(30)$ & 135 & 11 & $0.32 \pm 0.24$ \\
\hline
\end{tabular}

cies of 62 to $84 \%$ (with 1 retrieve) for Fundulus heteroclitus; these are similar to the estimated efficiency for capturing Gulf killifish with lift nets (Table 2). Flume weirs were more efficient than lift nets in sampling grass shrimp (42 to $72 \%$ ) and white shrimp (90\%). Zimmerman et al. (1984) also achieved high efficiency (91\%) collecting brown shrimp on marshes using a drop sampler. Lift-net efficiencies would also likely be less than those reported here for species that remain on the marsh at low tide or for smaller size classes (Kneib 1991). Using nets with a smaller mesh size might increase capture rates of small individuals

Possible explanations for the lift net being less than $100 \%$ efficient are: (1) some organisms avoided collecting pans and remained on the marsh or in the trench; (2) part of the sample was lost to predation by 
large nekton or birds; and (3) animals escaped through holes made in the net walls by blue crabs after the net was raised. It is unlikely that organisms were left in the sampling area, because sites were small enough to permit thorough inspection and removal of animals stranded on the marsh or in trenches. Strandings on the marsh seldom occurred. Occasionally, when the marsh did not completely drain, nekton was found in the trench, but organisms could usually be recovered using a small dip net. Predation within collecting pans is a possibility, but unlikely because animals that were forced into pans after the marsh drained were probably not hungry after having foraged on the marsh-surface and were likely in stress due to low oxygen conditions (Kneib 1991). The loss of nekton from the sampling area because of predatory birds did not appear to be a problem. Stiff wire stapled to the tops of the guide posts prevented their use as perches, and birds were seldom observed near sampling sites. The most plausible explanation for lowered efficiencies was that organisms escaped through holes made by blue crabs. Although large holes $(\geq 2 \mathrm{~cm}$ in diameter) were uncommon, most nets received some damage each time they were used, and when a sample contained few animals, the net was usually found to have at least 1 large hole. Undoubtedly, net efficiencies could be improved by using tougher netting or material that is more resistant to blue crab damage.

Although the accuracy of estimating densities of nekton on the marsh with the lift net was not assessed, the net has several characteristics that may enhance its efficacy over other methods. Unlike pull-up traps which work in a similar fashion (Higer \& Kolipinski 1967. Kushlan 1974), lift nets require relatively little habitat modification (even in dense vegetation) for site preparation or to collect a sample. Very few grass culms had to be cut and removed when constructing trenches, and over the course of this study I observed no changes in vegetation (increase or decrease in vigor relative to surrounding marsh) near trenches. When the net was buried, the trench became a narrow, very shallow depression around the sampling area, because most of its volume was filled by the net. Only walkway supports and guide posts protruded above the marsh surface at the sites (Fig. 2a). Therefore, natant organisms could swim unimpeded across the marsh surface and into the sampling area from any direction. This is a decided advantage over flumes and block nets, which have walls that block lateral movement of nekton, and require organisms to enter the mouths of these devices to be captured (Mclvor \& Odum 1986, Hettler 1989). Other samplers may require removing vegetation from the sampling area to insure efficient capture of nekton (Zimmerman et al. 1984, Rozas \& Odum 1987, Serafy et al. 1988). Methods that modify the habitat by adding structure or low-tide refugia may also bias density estimates by attracting organisms to the sampling sites. The walkway supports and posts required for using lift nets add little to the structure already present on vegetated marshes, and trenches are not unlike other shallow depressions that are common on the marsh surface. However, trenches did not serve as low-tide refugia, because the water level within trenches usually dropped below that of the buried net when the marsh surface drained. When repairing the nets at low tide, organisms were never observed residing in the trenches.

Because the net walls are raised from locations well removed from the sampling area, lift net sites are not disturbed prior to sampling. Other methods require maneuvering a small boat near the sampling area (e.g. drop sampler; Zimmerman et al. 1984) or walking around the sampling area on an elevated walkway to enclose it (e.g. flume weir; Kneib 1991).

The bottomless lift net is ideally suited for use in studies comparing nekton densities among intertidal microhabitats, because it is designed to sample small, discrete areas. For example, the net can be used to sample habitats that occur in small patches (tens of $\mathrm{m}^{2}$ ) or in linear strips too small or too narrow to sample using the flume net (McIvor \& Odum 1986) or flume weir (Kneib 1991). Because the net samples a fixed area, nekton density estimates can be readily made. Lift nets can be placed anywhere on the marsh surface and can be oriented in any direction. Their use is not confined to marshes adjacent to navigable water bodies as flume nets (McIvor \& Odum 1986), block nets (Hettler 1989), and drop samplers deployed from small boats (Zimmerman et al. 1984). Although I have described their use in a microtidal environment, lift nets were also used successfully in a South Carolina salt marsh where the tidal amplitude is much greater than in Louisiana (D. M. Allen pers. comm).

The bottomless lift net is relatively inexpensive to construct, operate, and maintain. The cost of materials to construct a single lift net is ca $\$ 175$. This does not include the cost of lumber needed to build walkway supports to the site, which will depend on the length of the walkway required. Three persons can install a lift net and prepare the site for sampling in ca $2 \mathrm{~h}$. Untreated, Delta-grade netting used to construct the lift nets has been used in the field for 14 mo without any noticeable deterioration. Holes are easily repaired using needle and thread, and 2 persons can check and repair 9 nets in less than $3 \mathrm{~h}$. Using treated netting may reduce blue crab damage and extend net life beyond that of untreated nets, but this has not been tested. However, treated netting must be flexible enough to easily fit into the trench and should not affect net efficacy through release of toxins. 
The lift net, like all sampling devices has its limitations. Although the area sampled by the lift net is greater than that of many other devices designed to sample vegetated environments (e.g. $2.8 \mathrm{~m}^{2}$ drop samplers, Zimmerman et al. $1984 ; 1$ or $2.25 \mathrm{~m}^{2}$ throw traps, Kushlan 1981) it is still relatively small. Adequate replication may alleviate some of the problems associated with using a small sampling area; even so, species that occur at very low densities or those with patchy distributions will likely be underrepresented in samples. The sampling area of the lift net could probably be expanded to $9 \mathrm{~m}^{2}$ with some minor modifications. However, where a larger sampling area is necessary, one should use a different device (e.g. flume weir; Kneib 1991).

In summary, innovations and improvements to existing sampling devices and methodologies have recently opened the way to studying nekton associated with intertidal wetlands, which had largely been ignored owing to the difficulty of sampling this environment (Zimmerman et al. 1984, McIvor \& Odum 1986). Development of the bottomless lift net offers an alternative to those devices now in use that require extensive habitat modification, block the free movement of organisms, or require sampling in close proximity to navigable waters. Lift nets allow one to acquire quantitative estimates of nekton densities that are comparable among a variety of intertidal habitats. Such information is crucial for advancing our understanding of how coastal wetlands function as habitat for estuarine species (Hettler 1989, Kneib 1991).

Acknowledgements. I thank R. T Kneib, M. W. LaSalle, C. C. Mclvor, and 3 anonymous reviewers for suggestions that improved the original manuscript. M. Goodly, M. T. Jackson, and G. S. Longman collected and processed most of the samples, and $\mathrm{P} C$. Caruso drafted the illustration of the net. Louisiana Land and Exploration Company granted leasepermission for use of study sites. This research was funded in

This article was presented by K. L. Heck Jr, Dauphin Island, Alabama, USA part by a grant from the Coastal Ocean Program Office of the National Oceanic and Atmospheric Administration through Grant Number NA90AA-D-SG779EHRP to the Louisiana Sea Grant College Program. The U.S. Government is authorized to produce and distribute reprints for governmental purposes, notwithstanding any copyright notation that may appear herein.

\section{LITERATURE CITED}

Hettler, W. F. (1989). Nekton use of regularly-flooded saltmarsh cordgrass habitat in North Carolina, USA. Mar. Ecol. Prog. Ser. 56: 111-118

Higer, A. L., Kolipinski, M. C. (1967). Pull-up trap: a quantitative device for sampling shallow-water animals. Ecology 48: $1008-1009$

Kneib, R. T (1991). Flume weir for quantitative collection of nekton from vegetated intertidal habitats. Mar. Ecol. Prog. Ser. 75: 29-38

Kushlan, J. A. (1974). Quantitative sampling of fish populations in shallow, freshwater environments. Trans. Am. Fish. Soc. 103: 348-352

Kushlan, J. A. (1981). Sampling characteristics of enclosure fish traps. Trans. Am. Fish. Soc. 110: 557-562

McIvor, C. C., Odum, W. E. (1986). The flume net: a quantitative method for sampling fishes and macrocrustaceans on tidal marsh surfaces. Estuaries 9: 219-224

Rozas, L. P., Odum, W. E. (1987). Fish and macrocrustacean use of submerged plant beds in tidal freshwater marsh creeks. Mar. Ecol. Prog. Ser. 38: 101-108

Serafy, J. E., Harrell, R. M., Stevenson, J. C. (1988). Quantitative sampling of small fishes in dense vegetation: design and field testing of portable 'pop-nets' J. appl. Ichthyol. 4: $149-157$

Shirzad, F. F., Klein, C. J. III, Orlando, S. P. Jr (1989). Revised physical and hydrologic characteristics for the Mississippi Delta Region estuaries. NOAA National Ocean Service. Rockville, MD

U.S. Department of Commerce. (1990). Tide tables 1991 high and low water predictions) east coast of North and South America, including Greenland. NOAA. National Ocean Service, Rockville, MD

Zimmerman, R. J., Minello, T. J., Zamora, G. (1984). Selection of vegetated habitat by brown shrimp, Penaeus aztecus, in a Galveston Bay salt marsh. Fish. Bull. U.S. 82: 325-336

Manuscript first received: April 30, 1992

Revised version accepted: October 29, 1992 